\section{SOI: 1.1/TAS DOI: 10.15863/TAS International Scientific Journal Theoretical \& Applied Science}

p-ISSN: $2308-4944$ (print)

e-ISSN: 2409-0085 (online)

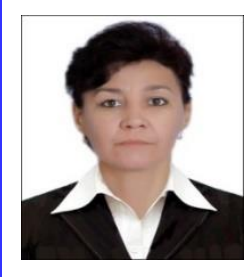

Volume: 55

Published: 29.11.2017 http://T-Science.org
Rano Gafurovna Abdullaeva

Senior teacher of

"Economic theory" department of Tashkent State University of Economics Republic of Uzbekistan, Tashkent city

Phone: +998909116089

SECTION 31. Economic research, finance, innovation, risk management.

\title{
THEORETICAL ASPECTS OF DEVELOPING HANDICRAFT ENTREPRENEURSHIP
}

Abstract: This article is devoted to the research of the role of handicraft entrepreneurship in the development of the national economy and its theoretical aspects. The main aim of studying theoretical aspects of the handicraft is its popularization as the main unit of the market economy with the account of compliance of its history with the Uzbek nation as well as its transition from one generation to the next one. The results of the research can facilitate the measures aimed at stimulating and developing national handicraft in our country, in particular, ensuring entrepreneurship of women, providing work places to the youth, enhancing the potential of the national tourism.

Key words: entrepreneurship, handicraft, handicraft development, theory of handicraft, history of handicraft.

Language: English

Citation: Abdullaeva RG (2017) THEORETICAL ASPECTS OF DEVELOPING HANDICRAFT ENTREPRENEURSHIP. ISJ Theoretical \& Applied Science, 11 (55): 240-244.

Soi: http://s-o-i.org/1.1/TAS-11-55-31 Doi: crossef https://dx.doi.org/10.15863/TAS.2017.11.55.31

\section{INTRODUCTION}

In conditions of the globalization of the world economy all developed countries are achieving their goals through the implementation of long-term development strategies. Adopting "Action strategy on further developing of Uzbekistan on five priority areas for 2017-2021" has given an impulse to the development of the socio-political and socioeconomic spheres of Uzbekistan. In the development of the national economy this strategy focuses mainly on small business and private entrepreneurship, traditional Uzbek handicraft. In particular, comprehensive support of the national handicraft and reforms aimed at the development, on the one hand, will be efficient for enhancing the potencial of the national tourism, on the other hand, involving women in the entrepreneurship activities and providing them with jobs. It should be noted that goods made by our craftsmen fascinate with their beauty and attractiveness not only our countrymen, but also foreign guests.

\section{URGENCY}

Although currently ongoing practical measures and activities are of a comprehensive nature, the researches of their theoretical foundations haven't been performed at the sufficient level. Thus it is considered to be necessary to ensure popularization of the handicraft as the main unit of the market economy with the account of compliance of its history with the Uzbek nation as well as its transition from one generation to the next one as well as to research its theoretical foundations. In this regard, it is urgent to research the theoretical aspects of the handicraft development.

\section{MAIN PART OF THE RESEARCH}

Handicraft appeared simultaneously with the production activity of the humanity. However, the notes about handicraft appeared later on. Preliminary data about handicraft in ancient India can be found in such opuses as "Upanishad"[1], "Arthasastra", "Laws of Manu" [2], "Ramayana" and "Mahabharata"[3].

"Arthasastra" presents the information about numerous types of crafts. "Laws of Manu" distinguishes "sinless" crafts and "sinful" crafts the use of which could cause death. Artistic handicraft was prohibited because as far as we know, rock paintings and drawing pictures of living beings on the walls have been existing since the times of primitive societies and being involved in such type of the handicraft was considered to be a sin.

Handicraft was considered to be the work of servants and slaves - Sudras. According to the laws of Manu one part of craftsmen which was one of four Varnas - Sudras, who were slaves, and other part consisted of Vayshs - free members who possessed 
all the rights. Since the first years of our era members of the society turned into dependant farmers and feudalism relations were developing. At that time farmers and the majority part of the craftsmen became to be treated as Sudras who did not possess full rights but Vayshas were considered as merchants.

In ancient Egypt the thoughts about handicraft were written in memorials and papyruses in the form of religious texts. They contained the information about the status of the craftsman, his relations with the ruler and his participation in the religious events. In ancient Babylon the inscriptions about handicraft were made in ceramic tables.

The Bible is also considered to be an important source for the information about handicraft. The Old Testament presents the history of the Jewish people, namely, the history of their household development [4]. The Talmud considers handicraft to be significant in the society. The data about handicraft management can be found in the New Testament.

The Old Testament associates the emergence of art and handicraft, which are almost the same with the appearance of cities. This source considers a person who worked with metal to be a craftsman. The Egypt literary sources demonstrate that handicraft was highly developed in ancient Syria and Xanaan. In addition, there were some notes about craftsmen who made arms. They wrote the orders in ceramic tables and moved from one place to another one. In the Second Book of the Old Testament (II Kingdom, 24, 14, 16) the arm makers were also named as craftsmen. Thus according to the Second Book of the Old Testament the people who dealt with stones and wood were also named as craftsmen. In Jewish language the word "craft", "craftsmen" assumes the person working with materials. It was stated that the ability to be a craftsman was gifted by the God [Exodus, 31, 3]. The Old Testament divides the labour of the craftsmen into the following branches: jewellery (The Book of Judjes, 17, 4; The Book of the Prophet Isain, 40, 12), Collectors of stones (I Cronic., 14, 1), Waterer (The Book of the Prophet Itinera 13, 11), Gardeners (The Book of the Prophet Isain, 44, 13).

The Talmud presents a comprehensive research of the handicraft activity [5]. This book is the first which determined necessity of protecting property rights of the handicraft and satisfying necessary requirements.

The Talmud also mentions the system of ancient jewish workshops. Crafts were transferred from a father to a son like inheritance and thus were kept inside this family. So particular crafts were considered as inherent welfare of the family. If anybody decided to move from one craft to another one he might face reprimand of the community. During the time of the Talmud the handicraft technique was highly developed. As "Exa rabe" states that with the aim of gaining skills of the culinary art and preparing 500 types of meals only from the grain flour he had to study for 5 years.

Like the Bible, the Talmud also illustrates the importance of the blacksmithing, in particular, it determines types of the blacksmithing and means of producing blacksmith items. In general it is possible to say that both the Talmud and the Old Testament consider handicraft activity to be an important part of the economy. Societies can neither exist nor develop without handicraft activities.

Ben-Sira defines various types of crafts and justifies the respect shown to craftsmen. Moreover, it states that it is impossible to imagine cities without them. Xenophon and Aristotle believed that handicraft labour lowered the personality thus they considered craftsmen to be an ordinary type of people.

Unlike the Old Testament, the Christian morality didn't look upon handicraft as an economic event. However, according to the New Testament it is said "...To labour and as a result to relax post mortem". Apostle Paul believed in necessity to deal with any type of craft and to work and he made a famous saying "Those that don't work, don't eat.".

In ancient China both Confucius, and Xun $\mathrm{Zi}$ and Meng $\mathrm{Zi}$ paid attention to handicraft [6]. China philosopher Xun Zi (III century BC) expressed the idea that all people were born with equal rights, so all of them had the right to use "Accumulated welfare" equally and common people should have equal rights for the land. At that time there were appeals to exempt farmers and craftsmen - slaves from the slavery.

In V-III centuries BC Sim Qian wrote "Historical notes" in which he mentioned that large handicraft workshops engaged in blacksmithing were operating. Thus, the economic system of the ancient China was researched [7].

Guang Zhong, the counselor of the ancient China in his treatise "Guang Zi" mentioned a high development of metallurgy works. "Guang Zi" classifies the population into four types: servants, farmers, craftsmen and merchants [8].

Guang Zhong wrote: "Ancient rulers managed to make servants, farmers, craftsmen and merchants exchange the results of their labour so at the end of the year there was no chance for anybody to get a lower income. The whole population worked equally and got the same income"[9].

Philosopher Mo Ji left some notes about various specialists - skilled casters, carpenters, jewelers, dray makers [10]. Due to special knowledge Mo Ji considered management to be a type of craft too. Profession of public officials is similar to the profession of the butcher, and administrative activity is compared to the wheel maker profession. Ancient Greek philosophers paid a particular attention to the handicraft. Since Xenophon handicraft was 
underestimated and was considered to be so-called "dirty work" [11].

Besides labour distribution among handicraft workshops Xenophon also mentioned distribution of labour inside workshops. In his opus "Cyropedia" he wrote: "In small towns one craftsman makes plank beds, a door, a plough, a table and in most cases, builds a house himself.... For sure, one person dealing with various crafts cannot prepare all of them equally well. On the contrary, in big cities there is a big demand for each item of goods and one craft is enough for each craftsman to support himself. In many places even one part of the craft is enough: for example, one craftsman prepares man's shoes, another one - woman's shoes. Sometimes one person prepares just a part of goods, craftsman cuts leather, the third one is engaged in tailoring, the fourth craftsman stitches all together and in this way all of them earn for living. It is obvious that those who are involved in the limited area of work, can do it best of all» [12].

Socrates said the following about the importance of handicraft in the ancient Greek public system: "Philosophers govern the country, military men are engaged in defense, and the lowest category of free people - craftsmen - deal with handicraft activities" [13].

Plato was the first who determined significance of the lab our distribution in economic development of ancient Greek cities - policies. From his point of view, distribution of the social labour if the basis of for the development. Thus Plato introduced the concept of the demiurge, creator - the God. In ancient Greek language Demiurgos means "handicraft". Thus saying "Chief Craftsman" implies the creator of the world, the God. Moreover, it is assumed that the God created the world, people and the gifts of the world with available means of production. In general, not only Plato, but also all religious books such as Avesta, Torah, the Bible, and Koran consider the God to be the Great Creator.

In the opinion of Plato, poverty and welfare are harmful for the development of the handicraft activity. He believes that both in case of possessing sufficient resources to make handicraft and in case of lacking enough money to start the work it will have a negative relation towards its activity. For example, as a potter becomes rich, his attitude towards his work will worsen because he will become lazy and won't respect his work. Another person due to the poverty won't be able to provide himself with tools for production and as a result can manufacture only lowquality goods. In addition, he will turn his children and trainees into bad craftsmen. Thus, both welfare and poverty can turn a skilled craftsman into the bad one. Moreover, welfare leads to laziness and indolence, and poverty - to subservience and rigid attitude towards creation of something new [14].
Plato has an objective approach towards handicraft - if one craftsman is rich, careless and negligent, he can be replaced by another craftsman, maybe not so rich but more skilled one or this fact can lead to the occurrence of speculators selling the goods made by other craftsmen.

Plato in his book "State" created a theory of the perfect social system and made a great contribution to the economic knowledge. He divided the people residing in the ideal "state" into three categories:

1. Philosophers.

2. Military men

3. ordinary category - land owners, craftsmen, merchants.

Herewith, the role of noble men (philosophers) is highly appreciated, because they are with another category - militaries (army) after organization of the public administration system, in the opinion of scientists, will govern the whole community. Meanwhile either philosophers or military men do not possess any right of ownership (in order not to confuse public benefits); their material security is assumed by the government on the basis of the equality principle. All household activities, in particular, ownership and its alienation are imposed on the third category of the ideal state - land owners, merchants and craftsmen. Slaves are considered to be property of free citizens and therefore the author of the "State" doesn't include them in any category [15].

Like Xenophon, Plato also considered farmers as the main branch of the economy and refer handicraft and trade to the insignificant activities. The views of Socrates and Plato were reconsidered by Aristotle in his opuses "Politics" and "Economics".

Likewise Plato, Aristotle put forward the idea of the project of the ideal government. The peculiarity of the Aristotle's project is that households and people are engaged in various types of activities. Each category of the population - land owners, cattlemen, craftsmen, merchants - is analyzed from the point of view of using accommodation facilities or earning welfare. Here Aristotle expressed the idea about the technique of earning and satisfying the needs and identified the concepts of economics and chrematistics. According to the opinion of Aristotle, economics is the main and respected activity related to farming, handicraft and petty trade. Its main aim is to satisfy the main needs of the people therefore the government should support it. Chrematistics is the art of enhancing welfare through the large volumes of trade. From the point of view of Aristotle, there is no limitation to achieve this aim because the main objective of this activity is to earn money and welfare and therefore this activity cannot be restricted. Unlike the economics, chrematistics is not considered to be important and contradicts to the laws of nature. Thus 
Aristotle made a conclusion that "Economics is worthy of praise and chrematistics is worthy of reprimand» [15].

In the East handicraft has also been developing from the ancient times. Eastern philosophers expressed their views about handicraft. As it is said in "Avesta", with the aim of having a prosperous life, our ancestors who were able to work, had to deal with any type of handicraft, namely, cattle breeding, farming, ant etc.

One of the main ideas expressed in the Holy Koran is that all Muslims are fraternal peoples and Arab tribes united around this flag. According to this holy book, the labour of craftsmen and farmers has a higher priority and the whole welfare is arisen on this basis.

Ibn Khaldun tried to show the main regularities of the social development. According to his opinion, the development of the human community constitutes the basis of the historical process. Initially people lived in the wild conditions. Then the human community emerged and during the process of its development it passed through two stages: "primitive" and "civilization". The first stage differs from the second one by the rule "how people find means of subsistence". If during the first stage people were mainly involved in farming and cattle breeding, in the second stage they dealt with handicraft, trade, science and arts.

Ibn Sino researched the main problems of the feudal society. Handicraft was considered to be an initial basis for this society. Ibn Sino wrote that "The needs of people for food and maintaining their power push all of them to learn crafts".

Yusuf Khos Hojib developed not only definition of the labour, but also paid attention to the labour distribution. He revealed peculiarities of the material welfare generated in farming, cattle breeding and handicraft. Yusuf Khos Hojib determined that namely labour of farmers feeds and dresses people, and cattlemen raise horses, camels and other animals used for eating and riding. Along with this, craftsmen make things necessary for living. In his book "Qutadgu bilig" (Knowledge leading to happiness), he divided people living in towns and villages into social layers - farmers, craftsmen, cattlemen, scientists, doctors and others - and highlighted the role of each in the life of the community. Moreover, he expressed the opinions about various professions, namely, farming, cattle breading and handicraft. He described farmers, craftsmen and cattle breeders as creators of the material welfare. He expressed his astonishment about craftsmen: "They are very necessary people..... ... blacksmith, tailor, cobbler, water carrier, saddler, bricklayer, archer, carpenter bring much use. My eyes got tired while counting them.... They bring benefits. They can make very many wonderful things". In addition, he made some recommendations to the public authorities related to the attitude to the working people.

Mahmud Qashgari in his book "Devoniy lugotit turk" ("Dictionary of Turkish words") wrote "Do good deeds to intelligent, wise people. Listen to their words. Gain knowledge, learn crafts and implement them in practice". The scientist appreciated clever people and craftsmen and called for taking an example from them.

During his reign Amir Temur paid attention to the further development of handicraft derived due to the large labour distribution - weaving, stonecarving, woodcarving, making carpets, producing metal and ceramic things as well as farming, cattle breeding and trade. Therefore new crafts appeared in the social life and massive unemployment was prevented.

In their opuses our ancestors highlighted the importance of handicraft for young people and their education. They considered learning crafts to be the main structural part of the education and upbringing. Moreover, our ancestors believed in necessity of making the youth learn crafts along with studying sciences, physical training and moral education. The youth was given instructions and recommendations how to select a profession with the account of individual capabilities and interests, carefully weighing all the arguments. Alisher Navoi mentioned the necessity of taking into account individual capabilities of the trainees saying that "Human beings are equal to nature but they have different merits".

Abu Raykhon Beruniy was the first in the history of mankind who expressed the idea about teaching crafts to young children since their early childhood, upbringing them with the idea of appreciating the labour of grown-ups, being the family focused on teaching science and professions to the children. The scientist especially highlighted the necessity of continuing labour education stared within the family with labour education at schools.

The great philosopher carefully studied succession of the labour and professions from generation to generation and highly appreciated handicraft activities of people. It is obvious that the comprehensive activities requiring a lot of hard work, deep knowledge facilitated widespread of ingenuity among craftsmen.

\section{CONCLUSION}

Advantages of learning crafts, their principles and rules have been revealed by numerous philosophers, scientists and wise men in their historical opuses and literary inheritance. Brochures about crafts represent advantages of crafts, their order, politeness, customs, rituals, and sacred ordinances.

In conclusion it should be noted that this kind of case studies made a big contribution to the 


\begin{tabular}{l|lrl|l|ll} 
& ISRA (India) & $=\mathbf{1 . 3 4 4}$ & SIS (USA) & $=\mathbf{0 . 9 1 2}$ & ICV (Poland) & $=\mathbf{6 . 6 3 0}$ \\
Impact Factor: & ISI (Dubai, UAE) $=\mathbf{0 . 8 2 9}$ & PUHL (Russia) $=\mathbf{0 . 2 0 7}$ & PIF (India) & $=\mathbf{1 . 9 4 0}$ \\
& GIF (Australia) & $\mathbf{0 . 5 6 4}$ & ESJI (KZ) & $=3.860$ & IBI (India) & $=\mathbf{4 . 2 6 0}$
\end{tabular}

development of the theory of learning crafts by our ancestors. Undoubtedly, efficient use of the scientific experience of our ancestors in teaching crafts to the youth will bring a positive effect.

\section{References:}

1. (2017) Upanishad. Available: http://psulib.org/ua/books/upani01 (Accessed: 10.11.2017).

2. (1960) Laws of Manu. M. Science. 1960.

3. (2000) History of Ancient world. Ancient East, Egypt, Sumerian, Babylon, Western Asia. M.2000

4. (2017) The Byble. Available: http://biblia.org.ua (Accessed: 10.11.2017).

5. (2017) The Talmud and oral Tora. Available: http://www.toldat.ru/rus_artikles.php/?cat_id (Accessed: 10.11.2017).

6. (2000) History of Ancient world. Ancient East, Egypt, Sumerian, Babylon, Western Asia. M.2000, p. 241-245.

7. Sim Qian (2017) Historical notes. Available: http://www.daolao.ru/sima_gian/sima_giansima (Accessed: 10.11.2017).

8. (2017) Conrad. Classical stage. Literature of ancient China. Available: http://febweb.ru/feb/ivl/vli/vll-1532.htm (Accessed: 10.11.2017).
9. (2000) History of Ancient world. Ancient East, Egypt, Sumerian, Babylon, Western Asia. M.2000, p. 241-247.

10. Mo Ji (2017) Craft of management. Available: http://china.worlds.ru/religion/xtan.html/ (Accessed: 10.11.2017).

11. (2003) Xenophon. Socratic writings. Cyropedia. M. ACT, 2003.

12. Asatullaev Kh., Djumanov D., Allaberganov Z., Khusanov D. (2014) History of economic knowledge. Collection of lectures.-T.:"Science and technology", 2014, 13-p.

13. (2003) Plato and Aristotle. Politics. Science on the state management. M. Eksmo, 2003, p. 366

14. (2003) Plato and Aristotle. Politics. Science on the state management. M. Eksmo, 2003, p. 106108.

15. Asatullaev Kh., Djumanov D., Allaberganov Z., Khusanov D. (2014) History of economic knowledge. Collection of lectures.-T.:"'Science and technology", 2014, 14-16 pp. 